\title{
PENGGUNAAN METODE KONTRASEPSI PADA WANITA USIA SUBUR DENGAN SIKLUS MENSTRUASI DI PUSKESMAS
}

\author{
Novia Purwaningsih Sailan \\ Gresty Masi \\ Rina Kundre \\ Program Studi Ilmu Keperawatan Fakultas Kedokteran \\ Universitas Sam Ratulangi \\ Email : Noviasailan@gmail.com
}

\begin{abstract}
Abstrack : A number of women complained that of use contraceptive methods caused menstrual problems. These problem can include having no periods at all until heavy and prolonged periods. The Purpose : this study to determine the relationship of the use of contraceptive methods in women of cycle. In the health center of Balehumara, Kelurahan Balehumara Kecamatan Tagulandang. The Research Design : the analytical survey that is used is with the cohort survey design. This research was conducted at the Balehumara Public Health Center in February - March 2109. The number of samples was 53 respondents, the research instrument used observetion sheets. The Results Research : based on result the tets statitic with use result fisher exact tets in the get the user cpntraception methods that to experience change cycle menstrual as much $(68,8 \%)$ and not experince change cycly menstrual as much (31,3\%) and in where scrore $p=0,005<$ a 0,05. The Conclusion: there is significant relationship between the use of contraceptive methods in women of childbearing age with menstrual cycle disorders in Balehumara Health Center.
\end{abstract}

Keywords : Menstrual Cycle Disorsers, Contraceptive Methode Users

Abstrak : Sejumlah perempuan mengeluhkan pemakaian metode kontrasepsi menyebabkan masalah menstruasi. Masalah tersebut dapat berupa tidak mengalami menstruasi sama sekali sampai menstruasi berat dan berkepanjang. Tujuan : penelitian ini untuk mengetahui Hubungan Penggunaan Metode Kontrasepsi Pada Wanita Usia Subur Dengan Siklus Menstruasi Di Puskesmas Balehumara Kelurahan Balehumara Kecamatan Tagulandang Induk. Desain Penelitian : yang di gunakan yaitu survei analitik dengan rancangan Survei Cohort. Penelitian ini di lakukan di Puskesmas Balehumara pada bulan Februari - Maret 2019. Jumlah sampel 53 orang responden, Instrumen penelitian menggunakan lembar Observasi. Hasil Penelitian : Berdasarkan hasil uji statistik dengan mengunkan uji Fisher's Exact Test di dapatkan penggunaan alat kontrasepsi yang mengalami perubahan siklus menstruasi sebanyak $(68,8 \%)$, dan tidak mengalami perubahan sebanyak $(31,3 \%)$, dan di mana nilai $p=0,005<$ a 0,05 . Kesimpulan : terdapat hubungan yang signifikan antara penggunaan metode kontrasepsi pada wanita usia subur dengan gangguan siklus menstruasi di Puskesmas Balehumara.

Kata Kunci : Gangguan Siklus Menstruasi, Penggunaan Metode Kontrasepsi 


\section{PENDAHULUAN}

Kontrasepsi merupakan cara yang digunakan untuk mencegah pertemuan antara sel telur (sel wanita) yang matang dan sel sperma (sel pria) yang mengakibatkan kehamilan. Dalam menggunakan kontrasepsi, keluarga pada umumnya mempunyai perencanaan atau tujuan yang ingin dicapai. Tujuan tersebut diklasifikasikan dalam tiga kategori, yaitu menunda atau mencegah kehamilan, menjarangkan kehamilan, serta menghentikan atau mengakhiri kehamilan atau kesuburan yang termasuk dalam keluarga berencana (KB) (Toduho, 2014). Usaha keluarga berencana (KB) terdapat beberapa aspek, salah satu aspeknya adalah penjarangan kemahamilan yang bertujuan meningkatkan derajat kesehatan ibu, yang mempengaruhi, baik terhadap bayi yang dilahirkan, anak yang dibesarkan, dan akhirnya keluarga secara keseluruhan (Prasetyawati,2012).

Metode kontrasepsi mengalami perkembangan dengan segala keuntungan dan kerugian dari masing - masing metode. Metode kontrasepsi dapat dibagi menjadi dua yaitu metode kontrasepsi jangka panjang (Longterm Contraceptive Method), yang termasuk metode ini adalah IUD (Intra Uterine Device) atau AKDR (Alat Kontrasepsi Dalam Rahim), Implant, Vasektomi dan Tubektomi. Sedangkan metode bukan jangka panjang (Non - Long Contraceptive Method), yang termasuk metode ini adalah suntik, pil, kontrasepsi vagina, dan kondom. Selain itu ada juga metode KB alami yang mengikuti siklus kehamilan (Susilowati,2015).

Kontrasepsi hormonal adalah alat atau obat untuk mencegah terjadinya kehamilan mengandung preparat estrogen dan progesteron. Kedua hormon-hormon tersebut bekerja sebagai penghambat pengeluaran folicel stimulating hormon dan leitenizing hormon sehingga menghambat proses konsepsi (Manuba, 2002). Kontrasepsi pil mengandung estrogen dan progesteron untuk menurunkan durasi dan jumlah perdarahan menstruasi, tetapi masih menimbulkan pendarahan intermiten. Kontrasepsi suntik mengandung progestin yang membatasi pola perdarahan berhubungan dengan tidak teraturnya menstruasi (amenorrhea) Kontrasepsi implan memiliki kadar estrogen rendah sehingga rata-rata jumlah darah yang keluar saat menstruasi lebih sedikit (Manuba, 2002).

Penggunaan kontrasepsi telah meningkat di banyak bagian dunia, terutama di Asia dan Amerika Latin dan terendah di Sub-Sahara Afrika. Secara global, pengguna kontrasepsi modern telah meningkat tidak signifikan dari 54\% pada tahun 1990 menjadi $57,4 \%$ pada tahun 2015. Secara regional, proporsi pasangan usia subur 15-49 tahun melaporkan penggunaan metode kontrasepsi modern telah meningkat minimal 6 tahun terakhir. Di Afrika dari 23,6\% menjadi 28,6\%, di Asia telah meningkat dari $60,9 \%$ menjadi $61,8 \%$, sedangkan Amerika latin dan Karibia naik sedikit dari $66,7 \%$ menjadi 67,0\%. Diperkiraan 225 juta perempuan di negara-negara berkembang ingin menunda atau menghentikan kesuburan tapi tidak menggunakan metode kontrasepsi apapun dengan alasan sebagai berikut: terbatas pilihan metode kontrasepsi dan pengalaman efek samping. Seperti bercak darah yang keluar secara tidak beraturan dan pengeluaran darah diluar haid serta mengakibatkan haid menjadi tidak lancar, maupun Kebutuhan yang belum terpenuhi untuk kontrasepsi masih terlalu tinggi. Ketidak adilan didorong oleh pertumbuhan populasi (WHO, 2015).

Menurut Kemenkes 2016 Persentase peserta KB aktif terhadap pasangan usia subur di Indonesia pada tahun2016 sebesar $74,8 \%$. Tiga provinsi yang memiliki persentase tertinggi yaitu Maluku Utara sebesar 87,03\%, Kepulauan Bangka Belitung sebesar 83,92\%, dan Sulawesi Utara sebesar $83,84 \%$. Sedangkan capaian terendah terdapat di Provinsi Nusa Tenggara Timur sebesar63,24\%, Sumatera Barat sebesar 63,73\%, dan DKI Jakarta sebesar 67,46\% (Kemenkes RI, 2016). 
Penggunaan kontrasepsi dapat menyebabkan siklus menstruasi menjadi tidak teratur karena terjadinya penurunan kadar hormon untuk mengatur siklus menstruasi. Hal ini sangat terkait dengan perubahan hormon dalam tubuh, perubahan hormon adalah menurunnya fungsi organ reproduksi yaitu ovarium yang bisa ditandai dengan memendeknya siklus menstruasi dan menyebabkan menstruasi tidak teratur (Hasti, 2016).

Menstruasi yang tidak teratur menunjukkan ketidak beresan pada sistem metabolisme dan hormonal. Dampaknya yaitu jadi lebih sulit hamil (infertilitas). Siklus menstruasi yang memendek dapat menyebabkan wanita mengalami ovulasi karena sel telur tidak terlalu matang sehingga sulit untuk dibuahi. Siklus menstruasi yang memanjang menandakan sel telur jarang sekali diproduksi atau wanita mengalami ketidak suburan yang cukup panjang. Apabila sel telur jarang diproduksi berarti pembuahan akan sangat jarang terjadi. Ketidak teraturan siklus menstruasi juga membuat wanita sulit mencari kapan masa subur. Siklus menstruasi idealnya teratur setiap bulan dengan rentang waktu antara 21-35 hari setiap kali periode menstruasi. Siklus menstruasi normal secara fisiologis menggambarkan, organ reproduksi cenderung sehat dan tidak bermasalah. Sistem hormonalnya baik, ditunjukkan dengan sel telur yang terus diproduksi dan siklus menstruasinya teratur sehingga dengan siklus menstruasi yang normal, seorang wanita akan lebih mudah mendapatkan kehamilan, menata rutinitas, dan menghitung masa subur (Ulum, 2016).

Gangguan pada siklus mensturasi dipengaruhi oleh gangguan pada fungsi hormon, kelainan sistemik, stres, kelenjar gondok, dan hormon prolaktin yang berlebihan. Gangguan dari stres mensturasi terdiri dari tiga, yaitu: siklus mensturasi pendek yang di sebut dengan polimenore, siklus mensturasi panjang atau oligomenore dan amenore jika mensturasi tidak datang dalam 3 bulan berturut - turut (Toduho, 2014).

Berdasarkan studi pendahuluan yang dilakukan peneliti pada 22 Juli 2018 di Puskesmas Balehumara, pemakaian Kontrasepsi Hormonal dan Non Hormonal seluruhnya berjumlah berjumlah 60 orang. KB suntik sebanyak 15 responden, pil KB 10 responden Implan 15 responden dan 12 responden memakai metode kalender, IUD. Selain itu hasil observasi danwawancara yang di lakukan peniliti didapatkan bahwa 15 responden KB suntik mengalami >3 (amenorea) atau pendarahan tidak teratur, 5 responden pil $\mathrm{KB}$ mengalami pendarahn bercak dengan pendarahn tidak teratur, 5 responden $\mathrm{KB}$ implan mengalmi pendarahan bercak bahkan ada yang terjadi peningkatan jumlah darah menstruasi, sedangkan yang memakai kontrasepsi Non Hormonal siklus mentruasi normal dan tidak ada pendarahan bercak. Berdasarkan studi pendahuluan diatas, maka peneliti tertarik untuk melakukan penelitian dengan tujuan mengetahui " Hubungan Penggunaan Metode Kontrasepi Pada Wanita Usia Subur Dengan Siklus Menstruasi Di Puskesmas Balehumara Kelurahan Balehumara Kecamatan Balehumara".

\section{METODOLOGI PENELITIAN}

Desain penelitian yang digunakan adalah jenis penelitian survei analitik dengan Rancangan Survei Cohort Penelitian Cohort atau sering disebut penilitian prospektif adalah suatu penelitian survei (noneksperimen) yang paling baik dalam mengkaji hubungan antara faktor resiko dengan efek (penyakit) (Notoatmodjo, 2010). Penelitian ini telah dilakukan di puskesmas balehumara pada bulan Februari-Maret 2019. Populasi dalam penelitian ini sebanyak 53 orang responden. Teknik pengambilan sampel ditentukan dengan rumus slovin sehingga sampel yang digunakan dalam penelitian ini berjumlah 60 orang responden. Uji yang di gunakan adalah uji fiher's exact test dengan nilai $p=$ 0,005 . Tingkat kepercayaan alfa $(a)$ yang 
digunakan yaitu: 0,05 . Jadi $p<a=0,05$. Instrumen pada penelitian ini menggunakan lembar observasi tentang hubungan penggunaan metode kontrasepsi pada wanita usia subur terhadap siklus menstruasi ini dibuat sendiri berdasarkan buku ajar Keperawatan Marternitas, Dan metode kontrasepsi yang digunakan responden yaitu hormonal seperti suntik, pil, dan implant, kontrasepsi hormonal diberikan skor 2, sedangkan metode kontrasepsi non hormonal seperti, IUD, metode kelender, dan kondom, di berikan skor 1, Dan Terdiri dari 3 pertanyaan dengan menggunakan jenis pertanyaan tertutup (closed ended) dengan 2 pilahan jawaban pada sebelum pemberian alat kontrasepsi yaitu ada perubahan dan tidak ada perubahan, dan bila ada perubahan di berikan skor 2 sedangkan bila tidak ada perubahan silklus menstruasi di berikan skor 1 (Mulyani dan Rinawati, 2013).

Teknik analisa data yang digunakan pada penelitian ini yaitu analisa univariat dan analisa bivariat. Analisa univariat pada penelitian ini bertujuan untuk mendeskripsikan setiap variabel diantaranya penggunaaan metode kontrasepsi pada wanita usia subur dengan gangguan siklus menstruasi Sedangkan analisa bivariat dilakukan terhadap dua atau lebih variabel yang diduga memiliki korelasi, yaitu penggunaan metode kontrasepsi pada wanita usia subur dengan gangguan siklus menstruasi. dengan menggunakan uji statistik Fishers Exact pada tingkat kepercayaan 95\% $(\alpha \leq$ 0.05).Etika Peneliti mempertimbangkan hak-hak subjek penelitian untuk mendapatkan informasi tentang tujuan peneliti melakukan penelitian tersebut. Disamping itu, peneliti juga memberikan kebebasan kepada subjek untuk memberikan informasi atau tidak memberikan informasi (berprestasi) Notoatatmodjo (2018).
HASIL dan PEMBAHASAN

1. Karakteristik Responden

Tabel 1. Distribusi Responden Berdasarkan Umur

\begin{tabular}{cll}
\hline Umur & n & $\mathbf{( \% )}$ \\
\hline $19-25$ Thn & 14 & 26,4 \\
$26-30$ Thn & 17 & 32,1 \\
$31-35$ Thn & 19 & 38,8 \\
$>35$ Thn & 3 & 5,7 \\
\hline Total & $\mathbf{5 3}$ & $\mathbf{1 0 0 . 0}$ \\
\hline
\end{tabular}

Berdasarkan tabel 1, umur responden terbanyak pada kelompok umur $31-35$ tahun yaitu sebanyak 19 orang reponden $(38,8 \%)$, sedangkan yang paling sedikit yaitu umur > 35 tahun ke atas sebanyak 3 orang responden $(5,7 \%)$.

Tabel 2. Distribusi Responden Berdasarkan Pendidikan.

\begin{tabular}{lll}
\hline Pendidikan & $\mathbf{n}$ & $\mathbf{( \% )}$ \\
\hline Tidak Tamat SD & 2 & 3,8 \\
SD & 2 & 3,8 \\
SMP & 11 & 20,8 \\
SMA/Sederajat & 33 & 62,3 \\
PT & 5 & 9,4 \\
\hline Total & $\mathbf{5 3}$ & $\mathbf{1 0 0 , 0}$ \\
\hline
\end{tabular}

Berdasarkan tabel 2, pendidikan responden terbanyak berpendidikan SMA/Sederajat yaitu sebanyak 33 orang responden $(62,3 \%)$ dan yang paling sedikit tidak tamat SD dan SD yaitu sebanyak 2 orang responden $(3,8 \%)$.

Tabel 3. Distribusi Responden Berdasarkan Pekerjaan

\begin{tabular}{lcc}
\hline Pekerjaan & n & $(\mathbf{\% )}$ \\
\hline PNS & 5 & 9,4 \\
Wiraswasta & 3 & 5,7 \\
Pegawai Swasta & 6 & 11,3 \\
Tidak bekerja/IRT & 39 & 73,6 \\
\hline Total & $\mathbf{5 3}$ & $\mathbf{1 0 0 , 0}$ \\
\hline
\end{tabular}


Berdasarkan tabel 3, pekerjaan responden terbanyak bekerja sebagai IRT yaitu sebanyak 39 orang responden $(73,6 \%)$ dan paling sedikit bekerja sebagai Wiraswasta yaitu sebanyak 3 orang responden $(5,7 \%)$.

Tabel 4. Distribusi Responden menurut jumlah anak

\begin{tabular}{lll}
\hline $\begin{array}{l}\text { Jumlah } \\
\text { Anak }\end{array}$ & $\mathbf{n}$ & $\mathbf{( \% )}$ \\
\hline 1 orang & 13 & 24,5 \\
2 orang & 26 & 49,1 \\
3 orang & 13 & 24,5 \\
4 orang & 1 & 1,9 \\
\hline Total & $\mathbf{5 3}$ & $\mathbf{1 0 0 , 0}$ \\
\hline
\end{tabular}

Berdasarkan tabel 4, jumlah anak responden terbanyak ada 2 orang yaitu sebanyak 26 orang responden $(49,1 \%)$ dan paling sedikit jumlah anak 4 orang yaitu sebanyak 1 orang responden $(1,9 \%)$.

\section{Analisis Univariat}

Tabel 5. Distribusi Jenis Kontrasepsi Yang Di Gunakan.

\begin{tabular}{lcc}
\hline $\begin{array}{l}\text { Penggunaan alat } \\
\text { kontrasepsi }\end{array}$ & n & $\mathbf{( \% )}$ \\
\hline Hormonal & 48 & 90,6 \\
$\begin{array}{l}\text { Non } \\
\text { Hormonal }\end{array}$ & 5 & 9,4 \\
\hline Total & $\mathbf{5 3}$ & $\mathbf{1 0 0 , 0}$ \\
\hline
\end{tabular}

Berdasarkan hasil penelitian diperoleh gambaran jenis kontrasepsi hormonal yang di gunakan sebanyak 48 orang responden $(90,6 \%)$, sedangkan jenis kontrasepsi non hormonal sebanyak 5 orang responden $(9,4 \%)$.

Tabel 6. Distribusi Siklus Menstruasi

\begin{tabular}{lcc}
\hline Siklus menstruasi & $\mathbf{n}$ & $\mathbf{( \% )}$ \\
\hline Tidak Ada & 20 & 37,7 \\
Perubahan & 33 & 62,3 \\
Ada Perubahan & & \\
\hline Total & $\mathbf{5 3}$ & $\mathbf{1 0 0 , 0}$
\end{tabular}

Berdasarkan hasil penelitian gambaran siklus menstruasi yang tidak ada perubahan sebanyak 20 orang responden $(37,7 \%)$, sedangkan siklus menstruasi yang ada perubahan sebanyak 33 orang responden $(62,3 \%)$.

\section{Analisis Bivariat}

Tabel 7. Analisis hubungan penggunaan alat kontrasepsi pada wanita usia subur dengan siklus menstruasi

\begin{tabular}{|c|c|c|c|c|c|c|}
\hline \multirow{3}{*}{$\begin{array}{c}\text { Jenis } \\
\text { Kontrasepsi }\end{array}$} & \multicolumn{6}{|c|}{ Siklus Menstruasi } \\
\hline & \multicolumn{2}{|c|}{$\begin{array}{l}\text { Tidak Ada } \\
\text { Perubaaha } \\
\text { n }\end{array}$} & \multicolumn{4}{|c|}{$\begin{array}{l}\text { Ada } \\
\text { Perubahan Total } p\end{array}$} \\
\hline & $\mathrm{n}$ & $\%$ & $\mathrm{n}$ & $\%$ & $\mathrm{n}$ & $\%$ \\
\hline Hormonal & 15 & 31,3 & 33 & 68,8 & & $\begin{array}{l}100 \\
0,005\end{array}$ \\
\hline $\begin{array}{l}\text { Non } \\
\text { Hormonal }\end{array}$ & 5 & 100 & 0 & 0 & 5 & 100 \\
\hline Total & 20 & 37,7 & 33 & 62,3 & 53 & 100 \\
\hline
\end{tabular}

Berdasarkan hasil penelitian diperoleh gambaran penggunaan alat kontrasepsi hormonal sebanyak 48 orang responden $(90,6 \%)$, sedangkan jenis kontrasepsi non hormonal sebanyak 5 orang responden $(9,4 \%)$. Dan gambaran siklus menstruasi ada perubahan sebanyak 33 orang responden $(62,3 \%)$, sedangkan siklus menstruasi yang tidak ada perubahan sebanyak 20 orang responden $(37,7 \%)$. Dari Hasil analisis statistik uji Fishers Exact di dapatkan nilai $p=0,005$. Tingkat kepercayaan alfa $(a)$ yang digunakan yaitu: 0,05 . Jadi $p<a=0,05$ sehingga Ho ditolak artinya terdapat hubungan yang signifikan hubungan penggunaan alat kontrasepsi pada wanita usia subur terhadap siklus menstruasi.

\section{Pembahasan}

1. Gambaran Metode Kontrasepsi Yang DiGunakan.

Berdasarkan hasil penelitian diperoleh bahwa gambaran penggunaan alat kontrasepsi di dapatkan responden lebih banyak menggunakan alat kontrasepsi hormonal, dibandingkan dengan alat kontrasepsi non hormonal, Sebagian besar responden lebih mengenal dan lebih memilih menggunakan alat kontrasepsi hormonal, karena alat kontrasepsi hormonal lebih efektif di bandingkan dengan alat kontrasepsi non hormonal. Hasil penelitian ini sejalan dengan 
penelitian yang dilakukan oleh (Sety, 2014) yang menunjukan sebanyak $70 \%$ responden lebih banyak menggunakan kontrasepsi hormonal. Kontrasepsi hormonal merupakan salah satu metode kontrasepsi yang paling efektif dan reversibel untuk mencegan terjadinya konsepsi.(Baziad, 2008). Kontrasepsi hormonal merupakan kontrasepsi dimanaestrogen dan progesteron memberikan upan balik terhadap kelenjar hipofisis melalui hipotalamus sehingga terjadi hambatan terhadap folikel dan proses ovulasi (Manuba 2010).

\section{Gambaran Siklus Mentruasi}

Sebagian besar responden tidak mengalami perubahan dalam siklus menstruasinya sebanyak 20 0rang responden $(37,7 \%)$, dan 33 orang responden $(62,3 \%)$ mengalami perubahan gangguan dalam siklus menstruasi. Gangguan tersebut diantaranya yaitu menerangkan banyaknya darah haid yang keluar, lamanya pendarahan, dan tidak mendapat haid sama sekali. Diantara 20 orang responden yang tidak mengalami perubahan siklus menstruasi terdapat 15 orang responden yang menggunakan metode kontrasepsi hormonal, menurut responden yang menggunkan kontrasepsi hormonal mereka merasa nyaman dan merasa cocok dengan kontrasepsi yang di gunakan karena metode kontrasepsi yang digunakan tidak terlalu banyak mengandung hormon estrogen dan progesteron atau hanya mengandung hormon estrogen sehingga siklus menstruasi tidak mengalami perubahan. Hasil penilitian ini sejalan dengan (susilowati 2015) yang menunjukan bahwa 93,3\% mengalami perubahan siklus menstruasi setelah menggunakan alat kontrasepsi.

Metode kontrasepsi hormonal dapat mengganggu siklus menstruasi karena kontrasepsi hormonal mengandung hormon estrogen dan progesteron sehingga memberikan umpan balik, terhadap perkembangan folikel fan proses ovulasi.
Melalui hipotalamus dan hipofisis, estrogen dapat menghambat pengeluaran $\mathrm{FSH}$ sehingga perkembangan dan kematangan folicel de graaf tidak terjadi.di samping itu progesteron dapat menghambat pengeluaran hormon LH. Dari pada itu responden yang menggunakan metode kontrasepsi hormonal kebanyakan mengalami gangguan siklus menstruasi karena terdapat hormon estrogen dan progesteron yang berlebihan (Kusmiran, 2011).

\section{Hubungan Penggunaan Metode}

Kontrasepsi Pada Wanita Usia Subur Terhadap Siklus Menstruasi Di Puskesmas Balehumara Hasil analisis statistik menggunakan uji Fishers Exact menunjukan nilai $p=0,005$ dimana nilai $p$ lebih kecil dari nilai $(\alpha)$ : 0,05 yang menunjukan bahwa terdapat hubungan penggunaan alat kontrasepsi pada wanita usia subur terhadap siklus menstruasi di puskesmas balehumara.

Penelitian yang telah dilakukan di puskesmas balehumara didapatkan 53 orang responden yang menggunakan alat kontrasepsi, 48 orang responden menggunakan alat kontrasepsi hormonal dan 5 orang responden lainnya menggunakan alat kontrasepsi non hormonal, dan sebanyak 15 (31,3\%) orang responden yang menggunakan alat kontrasepsi hormonal tidak mengalami gangguan siklus menstrusi karena responden merasa cocok dengan kontrasepsi yang diguanakan seperti kontrasepsi suntik atau pil. Sedangkan 33 $(68,8 \%)$ orang responden yang menggunakan alat kontrasepsi hormonal mengalami gangguan siklus menstruasi, karena dalam alat kontrasepsi hormonal mengandung hormon progesteron dan estrogen dimana hormon tersebut mempengaruhi hipotalamus dan hiposis sehingga menurunkan kadar FSH dan LH. Dengan demikian dari hasil penelitian yang dilakukan didapatkan hasil penelitian yang terbanyak penggunaan alat kontrasepsi hormonal. karena dalam metode 
kontrasepsi hormonal terdapat hormon progesteron dan hormon estrogen. Hormon progesteron dan estrogen terdapat dimetode kontrasepsi seperti motode kontrasepsi suntik, menurut teori metode kontrasepsi suntik adalah pemberian kontrasepsi suntikan sering menimbulkan gangguan siklus menstruasi (amenorhoe) (Faridah, 2005).

Hasil penelitian juga responden yang menggunakan alat kontrasepsi hormonal mengalami gangguan siklus menstruasi seperti alat kontrasepsi mini pil dan pil kombinasi. Mini pil adalah pil kb yang hanya mengandung hormon progesteron dalam dosis rendah tetapi mengakibatkan siklus menstruasi terganggu seperti bercak darah, spoting, amenorea dan tidak mendapat haid sma sekali, dan alat kontrasepsi pil kombinasi adalah pil yang mengandung hormon progesteron dan estrogen, singga mengakibatkan siklus menstruasi juga menjadi terganggu (Laely, dan Dyah, 2011).

Berdasarkan hasil penelitian di dapat penggunaan alat kontrasepsi hormonal lebih banyak responden yang terganggu siklus menstruasi karena menggunakan alat kontrasepsi hormonal seperti alat kontrasepsi implan adalah alat kontrasepsi yang di pasang di bawah kulit, implat juga mengakibat siklus menstruasi terganggu seperti pola haid yang berubah, spoting, dan amenorea (Laely, dan Dyah, 2011).

\section{SIMPULAN}

Berdasarkan penelitian yang telah dilakukan di wilayah kerja Puskesmas Balehumara pada tanggal 8 Maret 2019 maka dapat disimpulkan bahwa metode kontrasepsi terbanyak yang digunakan adalah metode kontrasepsi hormonal. Sebanyak 33 orang responden mengalami gangguan siklus menstruasi setalah pemakain metode kontrasepsi hormonal. Adanya hubungan yang bermakna antara hubungan penggunaan alat kontrasepsi hormonal pada wanita usia subur dengan siklus menstruasi di puskesmas balehumara.

\section{DAFTAR PUSTAKA}

Baziad, A (2008). Kontrasepsi Hormonal. Jakarta: PT Bina Pustaka Sarwono Prawirohardjo. (Buku. Hal 13)

Faridah, (2005). Perbedaan Pola Menstruasi Antara Pemakaian Alat Kontrasepsi Pil Dan Suntik Di Desa Getan Kecamatan Susukan Kabupaten Serang. Semarang : FKM UNDIP. Rescarh 12 juni 2019. (Skripsi 2005)

Hasti (2016). Pengaruh Penggunaan Alat Kontrasepsi Suntik Terhadap Menstruasi Di Wilayah Kerja Puskesmas Kotabu Kabupaten Muna Bulan Juli Tahun 2016.

Kemenkes RI (2017). Profil Kesehatan Indonesia 2016. September 23, 2018. Jakarta :Kementerian Kesehatan RI. https://www.depkes.go.id/resources/ download/

Kusmiran, E (2011). Kesehatan Reproduksi Remaja dan Wanita. Jakarta: Salemba Medika. (Jounar. Vol 21)

Laely, N, F dan Dyah, F. 2011. Perbedaan Pengaruh KB Suntik Depo Medroxi Progesteron Asetat (DMPA) dengan KB Implan Terhadap Gangguan Menstruasi Di Wilayah Kerja. Puskesmas 1 Purwonegoro Kabupaten Banjarnegara Tahun 2011. (Skripsi. Hal 4 - 5 )

Manuba, (2002). Ilmu Penyakit Kandungan dan Keluarga Berencana Untuk Pendidikan Bidan, 201-204, EGC, Jakarta: Rineka Cipta (Buku Hal 26) 
Mulyani, N.S, \& Rinawati, M (2013). Buku Keluaraga Berencana Dan Alat Kontrasepsi. Yogyakarta: Nuha Medika. ( Buku Hal. 24 - 363)

Notoadmodjo, S (2018). Metodologi Penilitian Kesehatan. Jakarta: PT Rineka Cipta. ( Buku Hal.201)

Prasetyawati, E.A (2012). Buku Kesehatan Ibu Dan Anak. Yogyakarta: Nuha Medika. (Hal. 23)

Susilowati, E. \& Prasetyo, E (2015). Faktor - Faktor Yang Berhubungan Dengan Siklus Menstruasi Pada Peserta KB Aktif Di Desa Jati Kulon Kecamatan Jati Kulon Kabupaten Kudus. September 23, 2018. https://ejr.stikesmuhkudus.ac. (vol. 6. No 1 Januari 2015)

Sety, M, L (2014). Jenis Pemakaian Kontrasepsi Hormonal dan Gangguan Menstruasi Di Wilayah Kerja Puskesmas Kendari. Kendari : FKM Universitas Halu Oleo Kendari. Rescarh 13 Juni 2019. (Volum. V, No 1.2014)

Toduho, S (2014). Hubungan Stres Psikologi Dengan Siklus Menstruasi Pada Siswi Kelas Satu Di SMA Negeri 3 Tidore Kepulauan. Oktober 13 , 2018. https://media.neliti.com/media/publi cations/107750. (vol 2, no 2. 2014)

Ulum, N (2016). Hubungan Antara Tingkat Stres Dengan Siklus Menstruasi Pada Mahasiswi Fisioterapi Universitas Hasanudin. September 20, 2018. https://repository.unhas.ac.id/bitstrea m/handle/ (Skripsi Hal 10-13)

WHO (2015) Family Planning/Contracepcion. Research $12 \quad$ oktober 2018. https//www.who.int/gho/poblications / 